\title{
Gender roles and practice of decision making on reproductive behavior among couples of Syangja district, Nepal
}

\author{
Sudarshan Subedi ${ }^{*}$, Preety Mahato ${ }^{2}$, Subina Acharya ${ }^{3}$, Hari Prasad Kafle ${ }^{1}$
}

\author{
${ }^{1}$ Lecturer, School of Health and Allied Sciences, Pokhara University, Kaski, Nepal \\ ${ }^{2}$ Public Health Officer, Western Regional Health Directorate, Kaski, Nepal \\ ${ }^{3}$ Nursing Instructor, Fewacity Institute of Medical Sciences, Pokhara, Kaski, Nepal
}

Received: 12 August 2013

Accepted: 17 August 2013

\section{*Correspondence:}

Dr. Sudarshan Subedi,

E-mail: subedisudarshan@gmail.com

(C) 2013 Subedi $\mathrm{S}$ et al. This is an open-access article distributed under the terms of the Creative Commons Attribution Non-Commercial License, which permits unrestricted non-commercial use, distribution, and reproduction in any medium, provided the original work is properly cited.

\begin{abstract}
Background: Reproductive behavior and its decision making practices are generally exercised in one of the three ways - mutual, dominancy of husband or dominancy of wife. Gender norms and roles prevalent in society affect the practice of reproductive decision making among couples. The aim of this study was to identify the practice of decision making on different reproductive behavior among couples and to examine the associated factors of decision making.
\end{abstract}

Methods: Descriptive cross sectional study was conducted in four Village Development Committee (VDCs) of Syangja district of Nepal by using structured interview schedule. The couples of reproductive age (15-49 years) having at least children of one year were the study population.

Results: Decision making on the use contraceptives and plan for pregnancy was mostly mutual $(62.1 \%$ and $74.8 \%$ respectively). Regarding the birth spacing, majority (42.4\%) of couples had made no decision followed by mutual decision $(41.4 \%)$. While $72.0 \%$ couples had gone through mutual discussion to maintain the family size, $27.7 \%$ discussed not at all regarding the concerned matter. Only $37.7 \%$ of husbands had provided adequate time for nurturing and caring their children. Association was found between decision maker on pregnancy and times of pregnancy $(\mathrm{P}<0.05)$, decision maker on birth spacing and interval between children $(\mathrm{P}<0.05)$, and employment status of husband and time provided by husband for nurturing and caring of baby $(\mathrm{P}<0.05)$.

Conclusion: Mutual decision making on reproductive behavior like pregnancy, birth spacing and family size symbolizes the initiation transformational gender norms and roles in Nepalese rural societies.

Keywords: Reproductive behavior, Gender, Couples

\section{INTRODUCTION}

Good reproductive health is the right of all individual including couples and requires responsibility sharing by both men and women. ${ }^{1}$ The International Conference on Population and Development (IPCD) - 1994 embraced a broader concept of reproductive health and rights including involvement of both men and women in all the matters of reproductive health and urged actions to ensure that men actively participate with women in concerned behavior. ${ }^{2}$ Gender norms and roles existing in particular society determine the access to or control over resources, power or decision making and roles and responsibilities between men and women which directly or indirectly affect the health status of both. Thus understanding gender provides insights into men's and women's behavior, relationship and reproductive decisions. ${ }^{3}$ Gender roles are reflected in virtually every society and its institution. Often males are more closely identified with the public world, waged work and the rights and duties of citizenship ${ }^{4}$ and females more closely associated with household chores with some sorts of agricultural works.

Male dominancy is prevalent in societies of most of the developing countries, the result of which as shown by different studies, men are found to be primary decision 
maker on different reproductive behaviors such as sexual activity, fertility, birth spacing and family planning, whereas married women lack control over decision related to sexual and reproductive behavior. ${ }^{5-7}$ Reproductive behaviors viz. contraceptive use, family size, breastfeeding habit, and prenatal care, when taken together were effective in predicting the relationship and decision making among couples. ${ }^{3}$ Traditional cultural and religious practices to a larger extent figure the gender norms and roles in every society. In Nepal, especially in rural areas and in some ethnic and religious communities, the prevalent of such norms and roles are preventing young girls and married women from making decisions about their reproductive lives. ${ }^{8}$ Moreover, men are in favor of their stereotypical behavior and inequitable gender norms and their attitude towards contraception is not positive. ${ }^{9}$

The objective of this study was to identify the practice of decision making on contraception, pregnancy, birth spacing, family size and nurturing \& caring of children; and to examine the factors associated with the practice of such decision making among couples.

\section{METHODS}

The study adopted a descriptive cross sectional design of quantitative approach. Four Village Development Committee (VDCs) viz. Phedikhola, Bhatkhola, Setidobhan and Faparthum, of Syangja district located in western hilly region of Nepal were selected for study. Further, proportionate sampling was done to identify the sample from each VDCs and finally systematic random sampling was adopted to identify the ultimate respondents. The couples of reproductive age (15-49 years) who had at least a child of one year were included in the study. The study period was ten months starting from July 2012 to April 2013. Interview schedule was used to collect related data and information. Interview schedule was made more practicable and convenient and confidentiality was maintained as high as possible. Data thus obtained was entered and analyzed using Statistical Package for Social Science (SPSS).

This study was approved by Research Committee of School of Health and Allied Sciences, Pokhara University. The purpose of study was clearly informed to the respondents and verbal consent was taken prior to interview. All the information collected was utilized only for the study purpose. Validity and reliability of the study was ensured through pre-testing of the interview schedule, trained enumerators involved in data collection and constant monitoring and supervision of their work.

\section{RESULTS}

A total of 440 participants who fit the selection criteria took part in study. The analysis performed was categorized in different groups under the headings as described below which includes - pattern of decision making on five reproductive behavior viz. contraception, pregnancy, birth spacing, family size and nurturing \& caring of children.

Contraception - Of the 440 participants, 65.5\% (288) had ever practiced any types of contraception, out of which $40.2 \%$ (177) were current users. Majority (45.2\%) of respondents were using condoms followed by pills $(42.9 \%)$, female sterilization $(4 \%)$, male sterilization (3.4\%), Depo and Implant $(2.3 \%)$. Decision maker of the currently used contraceptive device was made mostly by mutual decision (62.1\%) followed by husband's decision $(24.3 \%)$ and wife's decision $(13.6 \%)$ (Table 1$)$.

Table 1: Contraceptive use and decision making practice.

\begin{tabular}{|c|c|c|}
\hline $\begin{array}{l}\text { Contraception } \\
\text { practice }\end{array}$ & Frequency & Percentage \\
\hline \multicolumn{3}{|l|}{ Current user $(n=440)$} \\
\hline Yes & 177 & 40.2 \\
\hline No & 263 & 59.8 \\
\hline \multicolumn{3}{|c|}{ Currently used contraceptives $(n=177)$} \\
\hline Condom & 80 & 45.2 \\
\hline Pills & 76 & 42.9 \\
\hline Depo & 4 & 2.3 \\
\hline Implant & 4 & 2.3 \\
\hline Male Sterilization & 6 & 3.4 \\
\hline Female Sterilization & 7 & 4.0 \\
\hline \multicolumn{3}{|c|}{ Decision maker of current contraception $(n=177)$} \\
\hline Husband & 43 & 24.3 \\
\hline Wife & 24 & 13.6 \\
\hline Mutual decision & 110 & 62.1 \\
\hline
\end{tabular}

Pregnancy - The majority of respondents (33.6\%) were found to have 2 pregnancies, followed by 1 pregnancy $(32.5 \%)$ and 3 pregnancies $(23.4 \%)$. In general, the decision making of pregnancy was done by mutual decision $(74.8 \%)$ (Table 2).

Birth Spacing - The interval between two children was found to be 2 years in most of the cases (28.0\%). Majority (42.4\%) of couples had made no decision regarding birth spacing followed by mutual decision to be $41.4 \%$ (Table 3). 
Table 2: Pregnancy status and decision making practice $(n=440)$.

\begin{tabular}{|lll|}
\hline Characteristics & Frequency & Percentage \\
\hline Times of Pregnancy & & \\
\hline One & 143 & 32.5 \\
\hline Two & 148 & 33.6 \\
\hline Three & 103 & 23.4 \\
\hline Four & 23 & 5.2 \\
\hline Five & 20 & 4.5 \\
\hline Six & 3 & 0.7 \\
\hline Decision Maker of Pregnancy & \\
\hline Husband & 67 & 15.2 \\
\hline Wife & 44 & 10.0 \\
\hline Mutual decision & 329 & 74.8 \\
\hline
\end{tabular}

Table 3: Birth spacing and decision making practice.

\begin{tabular}{|c|c|c|}
\hline Characteristics & Frequency & Percentage \\
\hline \multicolumn{3}{|c|}{ Birth interval between two child (latest) $(n=297)$} \\
\hline 1 year & 39 & 13.1 \\
\hline 2 years & 83 & 28.0 \\
\hline 3 years & 64 & 21.6 \\
\hline 4 years \& more & 111 & 37.3 \\
\hline \multicolumn{3}{|c|}{ Decision maker of birth spacing } \\
\hline Husband & 24 & 8.1 \\
\hline Wife & 24 & 8.1 \\
\hline Mutual decision & 123 & 41.4 \\
\hline $\begin{array}{l}\text { No decision for } \\
\text { this/casual }\end{array}$ & 126 & 42.4 \\
\hline
\end{tabular}

Family size - While $72.0 \%$ couples had gone through mutual discussion to maintain the family size, $27.7 \%$ said that they didn't discuss about maintaining family size. In case of debate between husband and wife in maintaining the family size, $40.5 \%$ respondents argued that they will re-discuss and decide what to do; and in case of single decision maker, the study revealed that wife had dominancy over husband's decision (Table 4).

Nurturing and Caring of Children - While majority (70.2\%) of the respondents thought that it is not the sole responsibility of female spouse in nurturing and caring for children, it was found that only $37.7 \%$ of husbands had provided adequate time for nurturing and caring their baby. Majority $(61.5 \%)$ of husbands expressed that they had confidence in taking over the responsibility of caring children and send their wives out for work. In contrast, only $39.0 \%$ wives expressed confidence in handing over the responsibility of caring children to husband and go out to work (Table 5).

Table 4: Family size and decision making practice.

\begin{tabular}{|c|c|c|}
\hline Characteristics & Frequency & Percentage \\
\hline \multicolumn{3}{|c|}{ Discussion between couple to maintain family size } \\
\hline Yes & 318 & 72.3 \\
\hline No & 122 & 27.7 \\
\hline \multicolumn{3}{|c|}{$\begin{array}{l}\text { Decision on family size if the spouse are in oppose } \\
\text { with each other }\end{array}$} \\
\hline $\begin{array}{l}\text { It will be as the } \\
\text { wife wants }\end{array}$ & 127 & 28.8 \\
\hline $\begin{array}{l}\text { It will be as the } \\
\text { husband wants }\end{array}$ & 52 & 11.8 \\
\hline $\begin{array}{l}\text { Both will discuss } \\
\text { and decide }\end{array}$ & 178 & 40.5 \\
\hline $\begin{array}{l}\text { The condition has } \\
\text { not come yet }\end{array}$ & 83 & 18.9 \\
\hline
\end{tabular}

Table 5: Practice on nurturing and caring of children.

\begin{tabular}{|c|c|c|}
\hline Characteristics & Frequency & Percentage \\
\hline \multicolumn{3}{|c|}{$\begin{array}{l}\text { Respondent's view on sole responsibility of female in } \\
\text { nurturing \& caring of children }(n=440)\end{array}$} \\
\hline $\begin{array}{l}\text { Yes, female are solely } \\
\text { responsible }\end{array}$ & 131 & 29.8 \\
\hline $\begin{array}{l}\text { No, it's not the job of } \\
\text { female only }\end{array}$ & 309 & 70.2 \\
\hline \multicolumn{3}{|c|}{ Time provided by husband for child care $(n=440)$} \\
\hline Adequate time & 166 & 37.7 \\
\hline Some time & 128 & 29.1 \\
\hline Least time & 59 & 13.4 \\
\hline No time at all & 87 & 19.8 \\
\hline \multicolumn{3}{|c|}{$\begin{array}{l}\text { Husband's confidence to take over the responsibility } \\
\text { of caring children and send wife for outwork }(n=135)\end{array}$} \\
\hline Yes I can & 83 & 61.5 \\
\hline No I can't & 52 & 38.5 \\
\hline \multicolumn{3}{|c|}{$\begin{array}{l}\text { Wife confidence to handover the responsibility of } \\
\text { caring children to husband and go for outwork } \\
(n=305)\end{array}$} \\
\hline Yes I can & 119 & 39.0 \\
\hline No I can't & 186 & 61.0 \\
\hline
\end{tabular}


Association between variables - Analysis showed that educational status plays a significant role in the use of contraceptives $(\mathrm{P}=0.00)$. Association was found between decision maker on pregnancy and times of pregnancy $(\mathrm{P}<0.05)$, decision maker on birth spacing and interval between two latest children $(\mathrm{P}<0.05)$, employment status of husband and time provided by husband for nurturing $\&$ caring of children $(\mathrm{P}<0.05)$ (Table 6$)$.

Table 6: Association between different variables.

\begin{tabular}{|lllll|}
\hline $\begin{array}{l}\text { Independent } \\
\text { variable }\end{array}$ & $\begin{array}{l}\text { Dependent } \\
\text { variable }\end{array}$ & $\chi^{2}$ & df & P value \\
\hline $\begin{array}{l}\text { Educational } \\
\text { status of } \\
\text { husband }\end{array}$ & $\begin{array}{l}\text { Currently using } \\
\text { contraceptives }\end{array}$ & 59.781 & 4 & 0.000 \\
\hline $\begin{array}{l}\text { Educational } \\
\text { status of wife }\end{array}$ & $\begin{array}{l}\text { Currently using } \\
\text { contraceptives }\end{array}$ & 45.976 & 5 & 0.000 \\
\hline $\begin{array}{l}\text { Times of } \\
\text { pregnancy }\end{array}$ & $\begin{array}{l}\text { Decision maker } \\
\text { on pregnancy }\end{array}$ & 48.481 & 9 & 0.000 \\
\hline $\begin{array}{l}\text { Interval } \\
\text { between two } \\
\text { children (latest) }\end{array}$ & $\begin{array}{l}\text { Decision maker } \\
\text { on birth spacing }\end{array}$ & 56.029 & 15 & 0.000 \\
\hline $\begin{array}{l}\text { Employment } \\
\text { status of } \\
\text { husband }\end{array}$ & $\begin{array}{l}\text { Time provided by } \\
\text { husband for } \\
\text { nurturing and } \\
\text { caring of the baby }\end{array}$ & 93.955 & 12 & 0.000 \\
\hline
\end{tabular}

\section{DISCUSSION}

The study revealed that only $40.2 \%$ of respondents were currently using contraceptive devices, among which condom was the most preferable device. This percentage is lower than Nepal Demographic Health Survey - 2011 which showed that $43 \%$ of currently married women were using modern contraceptives, among which female sterilization $(15 \%)$ was found to be the most preferred method. ${ }^{9}$ A study regarding family planning selection discussion partners in Nepal showed that women seek contraceptive users to confirm their existing beliefs and behaviors related to contraceptive and family planning. ${ }^{10}$ Studies suggest that increasing male approval in FP matters and decreasing male dominance in such matters can be a major factor for success of FP programmes in developing countries. ${ }^{11,12}$ Such strategies can be helpful in further increasing use of contraceptive in Nepal. This study revealed that decision regarding family planning method was mostly mutual and it signifies the good husband-wife communication. Similar study done in Malay and Yoruba couples in Nigeria also reported the significant positive association between husband-wife communication on family planning and the current practice of family planning methods. ${ }^{13,14}$ In contrast to this, the result on decision on family planning is found to be different from the Nepal Demographic Health Survey - 2011 findings, which may be due to the presence of inequitable gender roles and norms in specific parts of country. This result is quite different from other similar studies done in developing countries which revealed that the decision making on contraception rather than being mutual or reciprocal, was an exclusive right exercised by husband. ${ }^{5,15}$

In accordance with this study, a study conducted in Nigeria concluded that majority of time, both men and women decide together regarding when to have next child, the agreement between partners' responses for this matter being $54 \% .^{14}$ Although, in most of the cases, husband and wives were found unaware of maintaining the interval between two children, the decision on maintaining family size was reported as mostly mutual decision of husband and wives. Some of the previous studies showed that the decision about family size is mostly done by husband. ${ }^{16,17}$ Yet another qualitative study informed that women exert greater influence than men in family size determination as well as inter-birth interval, women being more pronatalist than their husbands. ${ }^{18}$

Although most of the decisions in reproductive health were found to be mutual as per the findings of this study, involvement of husbands in nurturing and caring of children was seen less. Husband's involvement in child care is uncommon though husbands did participate in household chores like washing dishes or clothes, cooking or cleaning the house. ${ }^{19}$ The IPCD also draws attention to the unfairness inherent in many men's and women's gender roles, calling for men to take more responsibility for household and child-rearing. ${ }^{20}$ Studies have demonstrated that application of behavior change communication, social-cognitive intervention and other interventions are helpful and have positive impact on changing the behaviour and attitude of male in reproductive health related decisions. ${ }^{21,22}$

\section{CONCLUSION}

This research reported that, although the use of modern contraceptive is less, the practice of using male condoms was found more which signifies the involvement of men in context of using contraceptives. There is need to disseminate information regarding the use of modern contraceptives to overcome the low rate of contraceptive use. Mutual decision on different aspects of reproductive behavior like pregnancy, birth spacing and family size symbolizes the initiation transformational gender norms and roles in Nepalese rural societies. In contrast, the involvement of husband in nurturing and caring for the young children was found to be less; such practice was found to be influenced by gender norms and roles prescribed by concerned society which lead the way to education and employment status of men and women, and finally results in less interest and involvement of men in household chores. The study recommends for interventions aimed at increasing male involvement in related aspect as an imperative finding of this study. 


\section{ACKNOWLEDGEMENTS}

The authors are very much thankful to Pokhara University - Faculty of Science and Technology for providing financial support as well as to the Research Committee of School of Health and Allied Sciences for necessary technical and administrative support. All the respondents who provide data and information needed for the study deserve the high level of acknowledgement. Students of public health undergraduates of Pokhara University are thankful to their support during the process of data collection.

Funding: Faculty of Science and Technology, Pokhara University, Nepal

Conflict of interest: None declared

Ethical approval: Permission granted by Research Committee of School of Health and Allied Sciences, Faculty of Science and Technology, Pokhara University, Nepal

\section{REFERENCES}

1. Shrestha DR. Reproductive Health - National and International Perspectives. 1st ed. Dhulikhel: New Dhulikhel Printing Press; 2008.

2. United Nations Population Information Network. Report of the International Conference on Population and Development. CairoSeptember 1994.

3. Oladeji. D. Gender Roles and Norms Factors Influencing Reproducitve Behavior among Couples in Ibadan, Nigeria. Anthropologist 2008;10(2):1338.

4. Doyal L. Gender equity in health: debates and dilemmas. Social Science \& Medicine. 2000;51(6):931-9.

5. Aras R Y VI, D'souza N. Gender variables and reproductive behavior of women from rural Mangalore, South karnataka, India. International Journal of Collaborative Research on Internal Medicine and Public Health. 2012;4(3):167-76.

6. Bui Thi Thu Ha. Rohan Jayasuriya NO. Increasing male involvement in family planning decision making: trial of a social-cognitive intervention in ruarl Vietnam. Health Education Research. 2005;20(5):548-56.

7. Green CP. Male involvement in reproductive health and family planning. Programme Advisory Note/Technical Paper, UNFPAMIRH. 1994.

8. UNFPA. Reproductive Health. 2012; Available from: http://nepal.unfpa.org/en/programmes/reproductive. php.

9. Ministry of Health and Population; Government of Nepal. Nepal Demographic and Health Survey, 2011.
10. Boulay M, Valente TW. The selection of family planning discussion partners in Nepal. Journal of Health Communication. 2005;10(6):519-36.

11. Kamal N. The influence of husbands on contraceptive use by Bangladeshi women. Health Policy and Planning. 2000;15(1):43-51.

12. Schuler S, Rottach E, Peninah M. Gender norms and family planning decision-making in Tanzania: A qualitative study. Washington DC: C-Change. 2009.

13. Azimi YN, Atiya AS. Husband-Wife Communication and Family Planning Practices Among Malay Married Couples in Mukin Rusila, Terengganu. Medical Journal of Malaysia. 2003;58(2):218-28.

14. Feyisetan BJ. Spousal communication and contraceptive use among the Yoruba of Nigeria. Population Research and Policy Review. 2000;19:29-45.

15. Ezeh AC. The influence of spouses over each other's contraceptive attitudes in Ghana. Studies in Family Planning. 1993:163-74.

16. Caldwell J, Caldwell P. The limitation of family size in Ibadan, Nigeria: An explanation of its comparative rarity derived from in-depth interviews. Ebigbola JA, Renne ED, editors. Ibadan: African Book Publishers; 2000.

17. Adewuyi A, editor. Power and Privilege. The Male Issues in Fertility Transition in Nigeria, SubSaharan Africa. African population in the $21^{\text {st }}$ century Proceedings of the UAPS Conference; 1999.

18. Wusu O, Isiugo-Abanihe UC. Family structure and reproductive health decision-making among the Ogu of Southwestern Nigeria: A qualitative study. 2004.

19. Groenewold G, Horstman R, De Bruijn B. Gender and the Role of Men in Reproductive Health: Applications in studies on HIV Sexual Riskbehaviour in Zambia, Safe Motherhood in Nepal: Nethrlands Interdisciplinary Demographic Institute 2004.

20. United Nations Population Fund. International Conference on Population and Development, Cairo, Egypt, $1994 . \quad$ Available from: http://www.un.org/popin/icpd2.htm.

21. Ha BTT, Jayasuriya R, Owen N. Increasing male involvement in family planning decision making: trial of a social-cognitive intervention in rural Vietnam. Health Education Research. 2005;20(5): 548-56.

22. International Family Planning. Male Involvement in Reproductive Health: An assessment of the Behaviour Change Effectiveness of Information, Education and Communication 2005.

DOI: $10.5455 / 2320-1770 . i j r \operatorname{cog} 20130931$

Cite this article as: Subedi S, Mahato P, Acharya

S, Kafle HP. Gender roles and practice of decision making on reproductive behavior among couples of Syangja district, Nepal. Int J Reprod Contracept Obstet Gynecol 2013;2:414-8. 